\title{
Endurtekin krampaköst hjá ungri konu - sjúkratilfelli
}

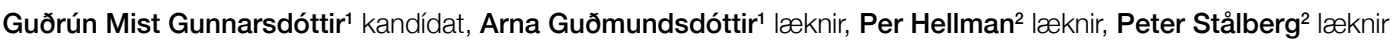

\section{ÁGRIP}

18 ára hraust stúlka kom endurtekið á slysadeild á 6 vikna tímabili vegna krampakasta. Engin fyrri saga var um flogaveiki og hún tók engin lyf. Myndrannsóknir og heilalínurit bentu ekki til flogaveiki. Hún mældist með lækkaðan blóðsykur í tvígang á slysadeild, 1,3 mmól/L og 1,7 mmól/L (4,0-6,0 mmól/L). Vaknaði pá grunur um insúlínmyndandi æxli. Gerð var víðtæk leit að æxlisvexti sem bar engan árangur. Var hún bví send erlendis i frekari uppvinnslu, meðal annars í jáeindaskanna og sérhæfða æðamyndatöku. Hún var að lokum greind með nesidioblastosis. Hér verður fjallað um sjúkratilfellið auk yfirferðar um pennan sjaldgæfa sjúkdóm og uppvinnslu á honum.
${ }^{1}$ Landspítala, í Uppsölum, Svípjód.

Fyrirspurnir: Guðrún Mist Gunnarsdóttir, gudrunmi@landspitali.is

Höfundar fengu sampykki sjúklings fyrir pessari umfjöllun og birtingu.

Greinin barst 14. desember 2015 , sambykkt til birtingar

7. apríl 2016.

Höfundar hafa útfyllt eyðublað um hagsmunatengsl.

\section{Tilfelli}

Átján ára hraust stúlka var flutt með sjúkrabíl á bráðamóttöku Landspítalans eftir að hún hafði fundist heima hjá sér sofandi að degi til pegar hún átti að vera að passa unga systur sína. Hún reyndist vera vanáttuð og með nýja áverka á andliti. Hún mundi ekki hvað hafði gerst pennan dag né dagana á undan. Hún kvartaði um ógleði og höfuðverk en engin merki voru um uppköst, pvag/hægðamissi eða bitsár í munni. Lífsmörk, blóðhagur, blóðsölt, blóðsykur, hjartalínurit og tölvusneiðmynd af höfði voru eðlileg. Hún hafði borðað vel kvöldið áður og um morguninn og ekki hafði borið á óeðlilegri hegðun pá. Hún sagðist ekki taka nein lyf. Síriti yfir nótt sýndi ekki hjartsláttartruflanir. Heilalínurit (EEG) sýndi hægar bylgjur frá báðum heilahvelum sem talið var syfjutengt eða eftirköst eftir flog (postictal). Talið var að hún hefði fallið í yfirlið og hugsanlega fengið heilahristing við fallið sem gæti skýrt minnisleysi undanfarins sólarhrings.

Viku síðar kom sjúklingur aftur á slysadeild, pá fjarræn og hæg í atferli. Hún hafði borðað vel í hádeginu og lagt sig í kjölfarið. Tveimur klukkustundum síðar sá aðstandandi að hún horfði stjörf fram fyrir sig og ekki náðist samband við hana. Pví var lýst pannig að hún hefði ekki verið með kippi en að pað hefði örlað á skjálfta í höndum og var hún pvöl af svita og hafði misst pvag. Taugaskoðun á slysadeild var ómarkverð. Lífsmörk og blóðhagur voru eðlileg við komu en blóðsykur mældist 1,3 mmól/L (4,0-6,0 mmól/L). Hún var meðhöndluð með glúkósalausn í æð á slysadeild og leið fljótlega betur. Insúlínmagn í blóði mældist 27,8 pmól/L á sama tíma og blóðsykur var lágur en insúlínmæling sem er $\geq 18$ pmól/L samtímis sykurfalli gefur til kynna að um umframmagn insúlíns sé að ræða. Sökum pess að sjúklingur neitaði staðfastlega að hún tæki sykursýkislyf var talið að um innræna insúlín-offramleiðslu (endogenous hyperinsulinism) væri að ræða. ${ }^{1}$ Vegna pessa vaknaði grunur um að hún gæti verið með insúlínæxli (insulinoma). Blóðgildi kortisóls, kalsíums, parathyroidhormóns, TSH og frítt T4 var eðlilegt. Ennfremur voru lifrar- og nýrnaprufur eðlilegar.

Segulómun af höfði var eðlileg. Skimun fyrir MCADD-erfðagalla (Medium-chain acyl-CoA dehydrogenase deficiency) reyndist neikvæð. Í mismunagreiningu var vöðvakippaflog ungmenna (juvenile myoclonic epilepsy, JME) en slíkt lýsir sér með krömpum en eðlilegu vöku-EEG og eðlilegri segulómun. Endurtekið EEG og svefn-EEG var gert og var pað eðlilegt. Hafin var meðferð með flogaveikislyfinu Levetiracetam (Zelta), par sem sjúklingurinn hafði fengið sitt fjórða alflog á 6 vikna tímabili. Við fimmtu komu á slysadeild eftir krampa 7 vikum síðar mældist blóðsykur á ný mjög lágur, aðeins 1,7 mmól/L. Sjúklingurinn fékk blóðsykurmæli með sér heim og staðfesti par endurtekin blóðsykurföll bæði fyrir og eftir máltíðir.

Sveltipróf með 72 klukkustunda föstu var gert vegna endurtekinna blóðsykursfalla. Pegar tæplega 24 klukkustundir voru liðnar af sveltiprófi fékk sjúklingurinn krampa. Á peim tímapunkti mældist glúkósi 1,3 mmól/L, insúlín mældist 50,0 pmól/L og C-peptí mældist 0,2nmól/L (insúlín $\geq 18$ pmól/L, C-peptíð 

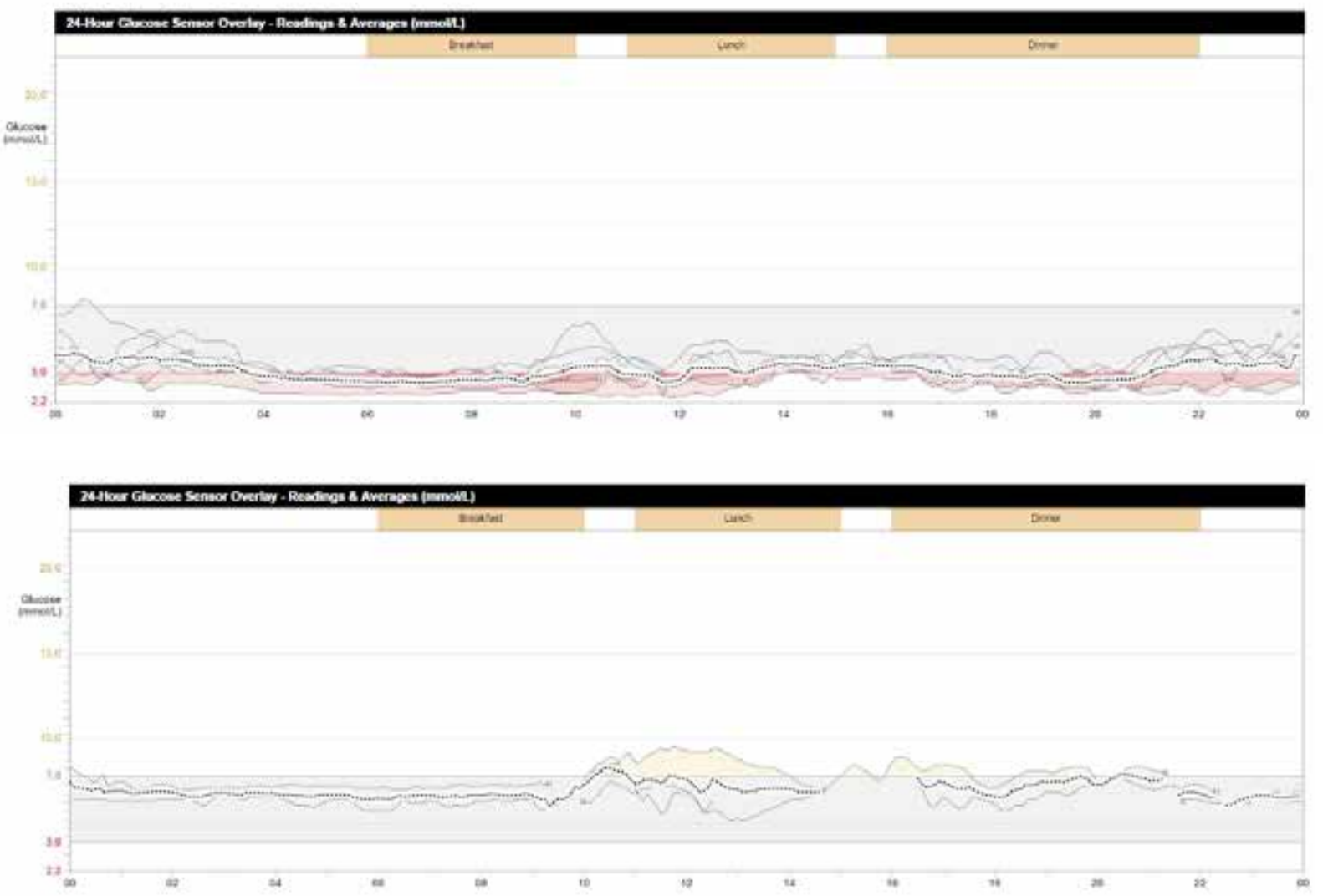

Mynd 1. Vikulöng blódsykursmæling með sírita fyrir aðgerd. Hver lína táknar einn sólarhring og punktalína táknar meðaltalsgildi. Eðlileg mörk blóðsykurs eru innan bláa svæðisins en blódsykurfall er innan rauða svæðisins. Blóðsykur sjúklingsins reyndist vera að meðaltali 4 mmól/L og hækkaði littið við máltíðir.

Mynd 2. Vikulöng blódsykursmæling með sírita eftir aðgerð par sem hluti brissins var fjarlægður. Blóðsykur sjúklingsins reyndist vera að meðaltali 6,3mmól/L. Blódsykur sjúklingsins helst pví innan viðmiðunarmarka mеð eðlilegri hækkun eftir máltíðir.
\0,2nmól/L samtímis sykurfalli gefur til kynna innræna insúlínofframleiðslu. ${ }^{1}$

Enn var sterkur grunur um insúlínæxli og voru pví gerðar myndrannsóknir til að staðsetja pað. Engin peirra rannsókna sem hægt er að gera hérlendis sýndu hnút í brisi, par með talin tölvusneiðmynd af kvið, segulómun af brisi og ómun af kviðarholi með holsjá (endoscopic ultrasound). Í kjölfarið var sjúklingurinn pví sendur á Háskólasjúkrahúsið í Uppsölum í Svípjóð til rannsóknar með jáeindaskanna. Par var gert stutt sveltipróf (8 klukkustundir) par sem blóðgildi insúlíns mældist 65,3 pmól/L, pro-insúlín var 33 pmól/L og C-peptíð var 0,36 nmól/L. Eins og áđur voru insúlín og C-peptíð-gildi lýsandi fyrir innræna insúlínframleiðslu. Ennfremur var pro-insúlíngildið styðjandi við pað, en nýlegar rannsóknir hafa sýnt fram á að pro-insúlíngildi $\geq 22$ pmól/L eftir föstupróf sé mjög sértækt fyrir innræna insúlínframleiðslu. ${ }^{2}$ Teknar voru tölvusneiðmyndir af brjóstholi og kviðarholi með skuggaefni í æð ásamt 11C-5HTP-jáeindaskanni. Einnig var endurgerð ómun af brisi með holsjá.

Niðurstöður úr pessum rannsóknum voru eðlilegar og sáust engin merki um æxli eða óeðlilega upptöku í líkamanum. Mælt var með sérhæfðri æðamyndatöku (selective angiography with celiacography), örvunarprófi með kalsíum (intraarterial calcium stimulation test) og endurteknu sveltiprófi.

Sjúklingurinn var pví sendur aftur út til Svípjóðar nokkrum mánuðum síðar í pessar rannsóknir. Æðamyndataka með kalsíumörvun var gerð á pann máta að kalsíum var sprautað í 6 meginstofnæðarnar sem næra brisið. Kalsíum örvar seytingu insúlíns á peim svæðum sem hver æð nærir og er pá hægt að mæla magn framleiðslunnar par á fjórum mismunandi tímapunktum. Ef mikil hækkun verður á seytingu insúlíns á stuttum tíma er pað merki um að insúlínæxli sé til staðar. Niðurstöðurnar voru bornar undir innkirtlasérfræðinga í Bandaríkjunum og Pýskalandi. Sameiginleg niðurstaða var sú að um offramleiðslu á insúlíni væri að ræða en ekki hefði fundist afmarkaður hnútur innan brissins sem væri valdur pess. Hér kom upp grunur um sjaldgæfan sjúkdóm sem veldur ofvexti brisfrumna en erfitt er að greina pann sjúkdóm nema með vefjasýni. Pví var ákveðið að taka sjúkling til aðgerðar, sem hún undirgekkst í Uppsölum. Fjarlægur (distal) 2/3 hluti brissins var fjarlægður ásamt miltanu eftir að myndrannsókn (68Ga-DOTATOC- jáeindarannsókn) sýndi ekki fram á nein ákveðin offramleiðslusvæði. Slík aðgerð er talin vera varanlegasta meðferðin við ofvexti brisfrumna.,4 Aðgerðin gekk vel og voru engir fylgikvillar eftir útskrift. Vefjagreining var framkvæmd á sýni frá aðgerðinni og var greiningin staðfest sem nesidioblastosis eða Noninsulinoma pancreatogenous hypoglycemia syndrome (NIPHS).

Fyrir aðgerð var framkvæmd vikulöng blóðsykursmæling með sírita til að geta fylgst með próun blóðsykursfallanna. Blóðsykur sjúklingsins reyndist vera að meðaltali 4 mmól/L og hækkaði lítið við máltíðir (sjá mynd 1). Gerð var samskonar vikulöng blóðsykursmæling tveimur mánuðum eftir aðgerð (sjá mynd 2). Par sést að blóðsykur helst í hærra og stöðugara gildi en áður og er hún alveg laus við blóðsykursföllin. Sjúklingur hefur nú verið laus við einkenni blóðsykursfalla í 9 mánuði. 


\section{Umræða}

Helstu mismunagreiningar hjá fullorðnum með blóðsykursfall vegna innrænnar insúlínofframleiðslu eru blóðsykurslækkandi lyf eins og sulfonylurea eða meglitinide, insúlínmyndandi æxli, NIPHS eða blóðsykursfall í kjölfar hjáveituaðgerðar (post-gastric bypass hypoglycemia).

Hægt er að greina blóðsykurslækkandi lyf í blóði eða pvagi. Til pess að greina insúlínæxli frá NIPHS parf að gera víðtæka leit að æxlisvexti í líkamanum. Ómun með holsjá er mjög næm rannsókn ( $990 \%$ ) til að staðsetja insúlínæxli og er pví oftast fyrsta rannsókn. ${ }^{5-7}$ Hins vegar getur pað ekki greint víðtæku vefjabreytingarnar sem einkenna nesidioblastosis. ${ }^{8}$

NIPHS er heilkenni sem einkennist af innrænni offramleiðslu insúlíns sem veldur blóðsykursfalli (endogenous hyperinsulinemic hypogycemia) sem er ekki af völdum insúlínæxlis. Insúlínæxli er mun algengari sjúkdómur og er NIPHS orsakavaldur blóðsykursfalla í kjölfar insúlínofframleiðslu í einungis 0,5-5\% heildartilvika. ${ }^{9}$

Nesidioblastosis var fyrst skilgreint árið 1938 af George F. Laidlaw. Par setti hann saman grísku orðin nesidion sem pýðir eyjafruma og blastos sem pýðir að byggja. Hér var hann í raun að lýsa próun frumnanna í heilkenni sem er pað sjaldgæft að pví hefur ekki verið lýst hérlendis áður. ${ }^{10}$

Vefjasýni frá briskirtlum pessara einstaklinga sýna ofvöxt beta-frumna, eyjur (islets) með stækkaðan og oflitaðan kjarna (hypercromatic) og aukna eyjafrumumyndun í kringum brisrásirnar (periductular islets). Pessir vefjafræðilegu eiginleikar eru einkennandi fyrir nesidioblastosis. ${ }^{11}$

Megineinkenni NIPHS er blóðsykursfall sem kemur í kjölfar máltíðar en ekki eftir tímabundna föstu. Rannsókn frá Mayo Clinic meðal 18 sjúklinga á aldrinum 16-78 ára sýnir að meirihlutinn $(70 \%)$ var karlkyns, í kjörpyngd og einkenni blóðsykursfalls komu oftast fram tveimur til fjórum klukkustundum eftir máltíð. Allir sjúklingarnir í rannsókninni höfðu upplifað einkenni sykurskorts í heila (neuroglycopenic symptoms) og sumir höfðu sögu um meðvitundarskerðingu og/eða alflog tengt sykurfalli. Tæplega helmingur sjúklingana (40\%) hafði undirgengist aðgerð á efri meltingarvegi, að undanskilinni hjáveituaðgerð, einhvern tíma á ævinni. Peir sem höfðu farið í hjáveituaðgerð voru útilokaðir par sem peir geta sýnt svipuð einkenni vegna hraðrar magatæmingar (dumping syndrome). ${ }^{3,12,13}$

Fáar rannsóknir hafa verið gerðar um petta heilkenni en nokkrar minni rannsóknir hafa sýnt fram á algengi blóðsykursfalla eftir máltíðir og eru karlar par í meirihluta. Athyglisvert er að margir pessara sjúklinga voru fyrst misgreindir með insúlínæxli en pau einkennast aðallega af blóðsykursföllum við föstu. Talið er að um 5\% sjúklinga með insúlínæxli fái einnig blóðsykursföll eftir máltíðir en fáar rannsóknir hafa verið gerðar pessu til staðfestingar. ${ }^{14}$

Meðan á sykurfalli stendur fá sjúklingar með NIPHS svipaðar rannsóknarniðurstöður og sjúklingar með insúlínæxli. Раð verður í flestum tilfellum hækkun á plasmainsúlíni, C-peptíði og pro-insúlíni.

Pví parf í kjölfarið að leita að æxlisvexti með pví að framkvæma sneiðmynd, segulómun, prífasa sneiðmynd (triple-phase CT), sérhæfða æðamyndatöku (celiac axis angiography) og jáeindarannsóknir. Ef ekkert finnst í pessum rannsóknum parf að framkvæma örvunarpróf með kalsíum (selective arterial calcium stimulation test with hepatic venous sampling (SACST)) sem hefur háa sértækni fyrir nesidioblastosis. ${ }^{15}$

Pegar einkenni NIPHS eru mjög væg er í sumum tilfellum hægt að meðhöndla upphafsstig sjúkdómsins með lífsstílsbreytingum. Pá er mælt með minnkaðri kolvetnaneyslu og að dreifa kolvetnainntöku jafnt yfir daginn. Við pessar næringarleiðbeiningar má bæta lyfjameðferð, diazoxide, alpha-glucosidasahemil eða octreotide sem gefið er með hverri stórmáltíð dagsins. ${ }^{16-19}$

Fyrir fólk með alvarlegri einkenni blóðsykursfalls, til dæmis einkenni sykurskorts í heila, er lyfjameðferð sjaldnast næg og aðgerð pví heppilegri kostur. Pá er oftast framkvæmt hlutabrottnám á fjærhluta brissins. Hlutfall brissins sem parf að fjarlægja fer eftir niðurstöðum úr SACST-rannsókninni. ${ }^{3,4}$ Bandarísk rannsókn sem skoðaði 5 sjúklinga sem undirgengust $70 \%$ brottnám af brishalanum sýndi fram á lága tíðni af blóðsykursföllum í kjölfar aðgerðar og enginn sjúklinganna hafði próað með sér sykursýki í kjölfar aðgerðar en eftirfylgdartíminn var 1,5-21 ár. ${ }^{20}$

Greint hefur verið frá endurkomu blóðsykursfalla eftir hlutabrottnám brissins. Lítil bandarísk rannsókn par sem $87 \%$ sjúklinga sem svöruðu könnuninni sögðust hafa fundið fyrir endurkomu einkenna en pó mun vægari en fyrir aðgerð. 75\% peirra töldu aðgerðina hafa bætt lífsgæði sín og heildarlíðan. Í örfáum tilfellum hefur purft að gera enduraðgerð par sem brisið var fjarlægt að fullu. ${ }^{21}$

Stökkbreytingar í 9 mismunandi genum hafa verið tengdar við sjúkdóminn í ungbörnum og er vonast til pess að áframhaldandi rannsóknir á pví sviði muni leiða í ljós hvaða sjúklingar munu hagnast af lyfjameðferð og hverjir munu purfa að fara í aðgerð. ${ }^{22}$ 


\section{Heimildir}

1. Cryer PE, Axelrod L, Grossman AB, Heller SR, Montori VM, Seaquist ER, et al. Evaluation and management of adult hypoglycemic disorders: an Endocrine Society Clinical Practice Guideline. J Clin Endocrinol Metab 2009; 94: 709-28.

2. Guettier JM, Lungu A, Goodling A, Cochran C, Gorden $\mathrm{P}$. The role of proinsulin and insulin in the diagnosis of insulinoma: a critical evaluation of the Endocrine Society clinical practice guideline. J Clin Endocrinol Metab 2013; 98: 4752-8.

3. Thompson GB, Service FJ, Andrews JC, Lloyd RV, Natt $\mathrm{N}$, van Heerden JA, et al. Noninsulinoma pancreatogenous hypoglycemia syndrome: an update in 10 surgically treated patients. Surgery 2000; 128: 937-44; discussion 44-5.

4. Raffel A, Krausch MM, Anlauf M, Wieben D, Braunstein S, Klöppel G, et al. Diffuse nesidioblastosis as a cause of hyperinsulinemic hypoglycemia in adults: a diagnostic and therapeutic challenge. Surgery 2007; 141: 179-84; discussion 85-6.

5. Kann PH, Rothmund M, Zielke A. Endoscopic ultrasound imaging of insulinomas: limitations and clinical relevance. Exp Clin Endocrino Diabetes 2005; 113: 471-4.

6. Sotoudehmanesh R, Hedayat A, Shirazian N, Shahraeen S, Ainechi S, Zeinali F, et al. Endoscopic ultrasonography (EUS) in the localization of insulinoma. Endocrine 2007; 31: 238-41.

7. McLean AM, Fairclough PD. Endoscopic ultrasound in the localisation of pancreatic islet cell tumours. Best Pract Res Clin Endocrinol Metab 2005; 19: 177-93.
8. Catton JA, Zaitoun AM, Aithal GP, Sturrock ND, Lobo DN. Diffuse nesidioblastosis causing hyperinsulinemic hypoglycemia: the importance of pancreatic sampling on EUS. Gastrointest Endosc 2008; 68: 571-2; discussion 72

9. Ramirez-Gonzalez LR, Sotelo-Alvarez JA, Rojas-Rubio P, Macías-Amezcua MD, Orozco-Rubio R, Fuentes-Orozco C. [Nesidioblastosis in the adult: a case report]. Cir Cir 2015; 83: 324-8

10. Laidlaw GF. Nesidioblastoma, the islet tumor of the pancreas. Am J Pathol 1938; 14: 125-34.5.

11. Anlauf M, Wieben D, Perren A, Sipos B, Komminoth P, Raffel A, et al. Persistent hyperinsulinemic hypoglycemia in 15 adults with diffuse nesidioblastosis: diagnostic criteria, incidence, and characterization of beta-cell changes. Am J Surg Pathol 2005; 29: 524-33.

12. Service FJ, Natt N, Thompson GB, Grant CS, van Heerden JA, Andrews JC, et al. Noninsulinoma pancreatogenous hypoglycemia: a novel syndrome of hyperinsulinemic hypoglycemia in adults independent of mutations in Kir6.2 and SUR1 genes. J Clin Endocrinol Metab 1999; 84: $1582-9$.

13. Rumilla KM, Erickson LA, Service FJ, Vella A, Thompson GB, Grant CS, et al. Hyperinsulinemic hypoglycemia with nesidioblastosis: histologic features and growth factor expression. Mod Pathol 2009; 22: 239-45.

14. Won JG, Tseng HS, Yang AH, Tang KT, Jap TS, Lee CH, et al. Clinical features and morphological characterization of 10 patients with noninsulinoma pancreatogenous hypoglycaemia syndrome (NIPHS). Clin Endocrinol 2006; 65: 566-78.
15. Thompson SM, Vella A, Thompson GB, Rumilla KM, Service FJ, Grant CS, et al. Selective arterial calcium stimulation with hepatic venous sampling differentiates insulinoma from nesidioblastosis. J Clin Endocrinol Metab 2015; 100: 4189-97.

16. Kellogg TA, Bantle JP, Leslie DB, Redmond JB, Slusarek B, Swan T, et al. Postgastric bypass hyperinsulinemic hypoglycemia syndrome: characterization and response to a modified diet. Surg Obes Relat Dis 2008; 4: 492-9.

17. Arao T, Okada Y, Hirose A, Tanaka Y. A rare case of adult-onset nesidioblastosis treated successfully with diazoxide. Endocr J 2006; 53: 95-100.

18. Moreira RO, Moreira RB, Machado NA, Gonçalves TB, Coutinho WF. Post-prandial hypoglycemia after bariatric surgery: pharmacological treatment with verapamil and acarbose. Obes Surg 2008; 18: 1618-21.

19. Kondo T, Tomita S, Adachi $\mathrm{H}$, Motoshima $\mathrm{H}$, Taketa $\mathrm{K}$ Matsuyoshi A, et al. A case of hyperinsulinemia of undetermined origin, successfully treated with long-acting octreotide. Endocr J 2005; 52: 511-7.

20. Witteles RM, Straus IF, Sugg SL, Koka MR, Costa EA, Kaplan EL. Adult-onset nesidioblastosis causing hypoglycemia: an important clinical entity and continuing treatment dilemma. Arch Surg 2001; 136: 656-63.

21. Vanderveen KA, Grant CS, Thompson GB, Farley DR, Richards ML, Vella A, et al. Outcomes and quality of life after partial pancreatectomy for noninsulinoma pancreatogenous hypoglycemia from diffuse islet cell disease. Surgery 2010; 148: 1237-45; discussion 45-6.

22. Gilis-Januszewska A, Piatkowski J, Skalniak A, PiwońskaSolska B, Nazim J, Pach D, et al. Noninsulinoma pancreatogenous hypoglycaemia in adults - a spotlight on its genetics. Endokrynol Pol 2015; 66: 344-54.

\section{ENGLISH SUMMARY}

\section{Repeated non-epileptic seizures in a previously healthy young woman - a case report}

Guðrún Mist Gunnarsdóttir¹, Arna Guðmundsdóttir¹, Per Hellman², Peter Stålberg²

A previously healthy 18 year old female has repeated admissions over a six week period to the emergency department because of seizures. She has no previous history of epilepsy and denies any drug use. Imaging and electroencephalogram do not indicate epilepsy. Blood sugar levels are low on two occasions, $1.3 \mathrm{mmol} / \mathrm{L}$ and $1.7 \mathrm{mmól} / \mathrm{L}(4.0-6.0 \mathrm{mmol}$ / L). After further investigations the suspicion of an insulin-producing tumor arises. Extensive research and imaging is conducted to look for tumor growth without any findings. Subsequently she was sent abroad for further evaluation with a 11C-5HTP-PET scan, selective angiography with celiacography and an intra-arterial calcium stimulation test. She was diagnosed with nesidioblastosis. Here we will discuss the presentation and work-up of the medical case and review this rare causative disease.

${ }^{1}$ Landspítali University Hospital of Iceland, ${ }^{2}$ Department of Surgical Sciences, University Hospital, Uppsala University, Sweden.

Key words: repeated seizures, neuroglycopenic symptoms, noninsulinoma pancreatogenous hypoglycemia syndrome (NIPHS), endogenous hyperinsulinemic hypoglycemia, nesidioblastosis.

Correspondence: Guðrún Mist Gunnarsdóttir, gudrunmi@landspitali.is 